UDC 811.111:81'364

DOI https://doi.org/10.32841/2409-1154.2021.49-1.34 Moiseienko S. M.,
Ph.D. in Philology,
Associate Professor at the Department of the English Language for Engineering No 1
National Technical University of Ukraine "Igor Sykorsky Kyiv Polytechnic Institute"

Lisetskyi K. A.,

Senior Lecturer at the Department of the English Language for Engineering № 1 National Technical University of Ukraine "Igor Sykorsky Kyiv Polytechnic Institute"

Kondrashova A. V., Lecturer at the Department of the English Language for Engineering № 1 National Technical University of Ukraine "Igor Sykorsky Kyiv Polytechnic Institute"

\title{
LEXICAL AND SEMANTIC PECULIARITIES OF TERMS OF THE MODERN ENGLISH SCIENTIFIC AND TECHNICAL DISCOURSE
}

\begin{abstract}
Summary. The specific nature, techniques and means of materialization of scientific and technical information transform and organize the material in some special way. The most important role is played by linguistic factors, without the analysis of which the understanding of the scientific and technical text is hardly possible. Modern language has a system of codes which is sufficient to convey any information. In scientific and technical language, the basic unit of the code system is a term i.e., a word or phrase that names a scientific and technical concept. The organization of any terminology system is always the result of a complex and lengthy process, as it depends not only on a number of factors and conditions, but also on their interaction. Obviously, the terminological system of the English language is continuously evolving, and the study of patterns of formation of the English terminological vocabulary and its structure is of the utmost importance for modern terminology science and linguistics. The English terminology, being complex and ambiguous, is in constant fluctuation, consequently it is becoming more crucial to clarify terms of the modern English scientific and technical discourse. Expanding of the professional vocabulary is entirely based on the systematization and classification of the term system. The article provides information about lexical and semantic features of the term system of modern English scientific and technical discourse; clarifies the specifics of the functioning of the terminological system by detecting its lexical, semantic and structural features, which is also the purpose of this work. It is emphasized that a detailed study of the regularities (patterns) of terminological vocabulary formation, its structure and semantic, making focus on the English terminological system, are important and necessary and this will definitely allow to enrich English scientific and technical discourse. The structural, lexical and semantic features of the terms are defined in the work. Their classifications have been specified and the characteristics, according to which they are classified, have been analyzed as well. A profound definition of the word 'term', its main characteristics and features are introduced.
\end{abstract}

Key words: term, terminological system, linguistic sign, lexical, semantic and structural features, scientific and technical discourse, professional vocabulary.
Formulation of the problem. The modern era is characterized by the rapid development of all branches of science and technology, the processes of their integration and international cooperation. The rapid growth of scientific and technological progress, global informatization, the introduction of new technologies in most areas of human activity also make significant changes in the linguistic model of the world, namely, in the field of terminology. Therefore, it is not surprising that nowadays specialized texts are increasingly found in the literature, and the majority of the linguistic fund is professional vocabulary (terms and nomenclature names).

At the same time insufficient study of lexical and semantic aspects of scientific and technical terms causes an increase in interest in scientific and technical discourse.

Of particular importance is the study of the laws of terminological vocabulary, its structure and semantics of the English terminology, because the role and importance of international professional relations, international cooperation increase. There is a constant exchange of experience in various fields in English.

Therefore, the object of our research is the terminological system of modern English scientific and technical discourse.

The aim of the study is to clarify the specifics of the functioning of the terminology of modern English scientific and technical discourse by identifying its lexical, semantic and structural features.

Review of recent research and publications on this issue. The works of such domestic and foreign linguists as K. Ya. Averbukh, N.D. Andreev, L.I. Bozhno, V.V. Vinogradov, A.S. Gerd, V.P. Danylenko, P.N. Denisov, V.M. Leichik, Yu.N. Marchuk, A.Ya. Shaikevich, S.D. Shelov are devoted to the study of the concept of term and terminological systems. Problems of formation, semantics, derivation and tendencies of development of terminological units, professional vocabulary, in particular, were studied by L.I. Vergun, O.O. Superanskaya, D.D. Lotte, B.B. Komarovsky, I.M. Kantor, V.V. Kraevsky, V.V. Makaev and others.

Presenting main material. The very concept of 'term' is quite complex and debatable. Term (from the Latin terminus - border, boundary) is a word or phrase that accurately and unambiguously defines a clearly stated special concept of any field of science, tech- 
nology, art, social life, etc. and its relationship with other concepts within a special field [1, p. 54]. Many translators also define this term. For example, Mostovy M.I. gives the following definition of the term: a term is a word or phrase with a historically motivated or conditionally fixed meaning, which reflects one concept in a specialized field of knowledge or production [2, p. 92]. Karaban V.I. defines the term as a linguistic sign that represents the concept of a special, professional field of science or technology. He believes that scientific and technical terms are an essential component of scientific and technical texts [3, p. 95].

Among the main features of the term are: conciseness, unambiguity, simplicity, motivation (correlation of the term with other terms of the same system or words of the common language), systemicity (consistency with other terms), highly informativeness and accuracy.

An important feature of the terms of any industry is that they accurately express the concepts, processes and names of things that are characteristic of a particular field of production. This is facilitated by a clear structure of construction of terms of scientific and technical discourse [4].

According to the structural and semantic features, the terms are divided into terms expressed in one word (ultrasensor - ультрасенсор), terms-phrases (explosive motor - двигун внутрішнього згоряння) and multicomponent terms (low-gravity fuel - паливо з малою питомою вагою). In turn, the terms, expressed in one word, on the morphological basis of the main word are divided into simple (program - комn'ютерна програма), derivatives (cleaner - очищення) and complex (keyword - ключове слово), and terms-phrases - into the noun (entitlement - права), adjectives (mandatory-обов'язковий) and verbs (generate - виробляти).

The terminological system of the English language is always updated, and the study of patterns of formation (derivation) of the English terminological vocabulary and its structure is one of the most important tasks for modern terminology science and linguistics, which requires some systematization and standardization. The English terminology, being complex and ambiguous, is in constant fluctuation. Therefore, it is necessary to learn some basic principles of the derivation of the English terms that objectively exist in the system of each developed language.

For the formation of the English terminology lexical units such methods as affixation, morphological derivation, abbreviations are often used. The predominant affixal form of English terms is the suffixation that occurs with such derivatives: -er (cleaner); -ing (balancing); -ion (compression); -or (generator); -ment (adjustment);ance (clearance).

Less common in English terminology is prefixation. Mostly, derivative functions take on prefixes such as: re- (reconnect), being added to the verb; anti- (antifreeze); auto- (autohoist); trans- (transaxle) added to the noun; to either noun or verb inter- (interact); under- (underproduce); dis- (disjoin); un- (unfordable); in- (infus$i b l e$ ) - to the adjective.

An important method of the English term formation is morphological derivation as well. Combining the words of different parts of the speech (we can combine the noun with the noun (tip-substrate), the adjective with the noun (double-acting), the adverb with the noun (all-metal), the verb with the adjective (standstill), we can add the participle II to the noun (armour-plated), or combine it with the numerals (four-door), or the adjective combine with the participle I (long-wearing) we get new terms.
Contraction as a way of term formation is also common in the English terminology. Among the contractions formed by the transformation of words, we can distinguish: truncation - det (detachment); telescopic words - amtrac (amphibious tractor) and alphabetic contractions (abbreviations) - bsh (bushel). Letter contractions are divided into the actually abbreviations - BBC (front of bumper to back of $c a b$ ) and acronyms, which include abbreviated words derived from the initial letters or syllables of the nominative phrase - CAP (cleaner air package).

Hence, semantic and morphological derivations are considered to be the main formation means (tools) of the English terminology (Table 1).

An equally important aspect of the study of terms is their classification. Terms are classified according to various lexical and semantic features.

Among the main grammatical and lexical features of scientific and technical texts, we can highlight the following ones: the use of special forms of verbs, the use of impersonal and indefinite-personal sentences and preference for the present tense, the use of many complex nominations and words with abstract, generalizing meaning, the use of many terms.

Our observations on the lexical features of the scientific and technical text show that the language of this genre of scientific style is heterogeneous, which is due to the thematic diversity of the materials disclosed in it. There are three main thematic subsystems of vocabulary in scientific and technical texts that correlate with the three main pragmatic settings of scientific and technical text - the description of the phenomenon, the creation of a metalanguage to describe the phenomenon and the author's attitude to the phenomenon being described. This is the vocabulary that belongs directly to the subject of presentation and is a certain terminological system, i.e. terminological vocabulary, which enshrines the names of substances, tools, technological processes: methine hydrogen, acid crystal residue, depleteduranium, diode, laser, radiation protection conductor, oil products; vocabulary that belongs to the procedure of describing the relevant process, action, phenomenon, etc., which terminology is no longer fully, although not fully multifunctional: destructive analysis, ionization, specific weight, universal gravity, rotary motion, feed motion; after all, the vocabulary that serves to infer the author himself and which is multifunctional: considerable body of evidence, no exceptions in the data, from the outcome of our investigations, research carried by the authors, the existence of (these effects) implies that. Here subjective evaluation is most evident, the figurative use of lexical elements is observed. Synonymy is developed in general scientific vocabulary. Most options are synonymous and interchangeable.

Therefore, we can say that stable and free units play an important role both in purely scientific prose and in scientific and technical text in particular. They are linguistic tools that provide a logical presentation of information and distinguish it as an essential feature of the presentation of scientific information in various genres.

Free terminological phrases are phrases that are used each time in a lexically updated form, i.e., the main word can be updated each time or have dependent components, for example: адсорбиійнеочищений нафтопродуктів (stable phrase) - очистка нафтопродуктів (free phrase); иентралізоване теплопостачання (stable phrase) деценттралізоване теплопостачання (free phrase) [5, p. 49].

Stable verbal complexes perform their functional role in general scientific texts (scientific academic substyle, for example: the sub- 
Table 1

Formation means (tools) of the English terminology

\begin{tabular}{|c|c|c|c|}
\hline $\begin{array}{c}\text { Method of term } \\
\text { formation }\end{array}$ & Type of term formation & The tool of termination & Examples \\
\hline \multirow[t]{2}{*}{ Affixation } & Suffixation & $\begin{array}{l}\text {-er } \\
- \text { ing } \\
\text {-ion } \\
\text {-or } \\
\text {-ment } \\
\text {-ance }\end{array}$ & $\begin{array}{l}\text { cleaner - очищення; } \\
\text { balancing - балансування; } \\
\text { compression - стиснення; } \\
\text { generator - генератор; } \\
\text { adjustment - корегування; } \\
\text { clearance - оформлення }\end{array}$ \\
\hline & Prefixation & $\begin{array}{l}\text { re-V } \\
\text { anti-N } \\
\text { auto-N } \\
\text { trans-N } \\
\text { inter-N,V } \\
\text { under-N, V } \\
\text { dis-N,V } \\
\text { un-A } \\
\text { in-A } \\
\end{array}$ & $\begin{array}{l}\text { reconnect - пере підключення; } \\
\text { antifreeze - антифриз; } \\
\text { autohoist - автопідйомник; } \\
\text { interact - взаємодія; } \\
\text { transaxle - коробка передач; } \\
\text { underproduce - нестача; } \\
\text { disjoin - pоз'єднання, розпад; } \\
\text { unfordable -недоступний; } \\
\text { infusible - непереборний } \\
\end{array}$ \\
\hline $\begin{array}{l}\text { Morphological } \\
\text { derivation }\end{array}$ & $\begin{array}{l}\mathrm{N}+\mathrm{N} \\
\mathrm{A}+\mathrm{N} \\
\mathrm{Adv}+\mathrm{N} \\
\mathrm{V}+\mathrm{Adv} \\
\mathrm{N}+\mathrm{P} \\
\mathrm{A}+\mathrm{P} \\
\mathrm{Num}+\mathrm{N}\end{array}$ & & $\begin{array}{l}\text { tip-substrate - система 'вістря-підкладка'; } \\
\text { double-acting - подвійна дія; } \\
\text { all-metal - все металеве; } \\
\text { standstill - зупинка; } \\
\text { armour-plated - броньована; } \\
\text { long-wearing - зносостійкість; } \\
\text { four-door - чотирьохдверні } \\
\end{array}$ \\
\hline \multirow[t]{3}{*}{ Contraction } & Truncation & & det (detachment - загін) \\
\hline & Telescopic words & & amtrac (amphibious tractor - трактор амфібія) \\
\hline & $\begin{array}{l}\text { Alphabetic contractions } \\
\text { (abbreviations) } \\
\text { - actually abbreviations } \\
\text { - acronyms }\end{array}$ & & $\begin{array}{l}\text { bsh (bushel - бушель, безліч); } \\
\text { PC (personal computer) - персональний комп'ютер, VR (virtual reality) - } \\
\text { штучно створений світ; } \\
\text { FORTRAN (Formula Translation) - Фортран }\end{array}$ \\
\hline
\end{tabular}

ject of research is characterized by free form, connected form, etc. Established lexical complexes are often found in engineering texts (scientific and technical substyle) [2, p. 98].

Based on this, the ability to reproduce in the finished form, articulation without distortion of semantic-syntactic unity is impossible, so terminological phrases of a stable nature may be similar to phraseology, for example: electrical systems (terminological unit). Phraseological units include those that can reflect the development of the national language or history [1, p. 130].

Despite this, there are distinctive features. There is no emotional color in terminological combinations that are stable, in addition, if a new word is added, one of the components may change, and with it the meaning of the compound, then a new concept is formed, for example: температура сухого термометра (stable phrase) - не прогнозована температура мокрого термометра (free phrase) [1, p. 121].

Thus, stable terminological combinations and the ability to reproduce them many times in the finished form provide an opportunity to preserve the originality of the scientific and technical text without compromising the content. Stable compounds are inherent in all layers of scientific vocabulary, so the dynamic changes in stable terminological combinations are inextricably linked with the need to create and express new meanings. It should also be noted that stable terminological compounds, in contrast to free phrases, provide a logical presentation of information in the scientific and technical text, and contribute to the reproduction of genre features of the text.
It is a well-known fact that the basis for the formation of terminology is literary language. Therefore, there is reason to believe that the terminology has the same patterns and specific features that operate in literary language [6]. Therefore, there are lexical-semantic processes characteristic of the lexicon in general in the terminology: polysemy, homonymy, synonymy, antonymy, paronymic relations.

Conclusions and prospects of the study. Scientific and technological progress makes significant changes in all spheres of society, including the linguistic picture of the world, due to which there is an urgent need to improve the system of transmission and processing of information, cooperation of scientists from different countries in various fields of science and technology. One of the most significant changes is that the vast majority of the linguistic fund is professional vocabulary, and the share of terms in the lexical structure of the language is growing rapidly. Therefore, it is quite natural that linguists attach great importance to the study of the laws of formation of terms, their structure and semantics, aspects of ordering, translation issues; consider terminology as an important component of modern literary language.

Thus, the peculiarities of the terminological system of the English language scientific and technical discourse require detailed study, because science and technology do not stand still, but develop rapidly, which themselves occupy an important place in society today. Without such a terminological system, it will be impossible not only to exchange scientific and technical information, but also to develop further science and technology. 


\section{References:}

1. Ботвина Н.В. Офіційно-діловий та науковий стилі української мови. Київ : АртЕк. 1998. 190 с.

2. Бабич Н.Д. Стилі, підстилі чи жанри літературної мови. Наук. вісник Чернівецького держ. ун-ту: Слов. філологія. 2002. Вип. 93. Чернівці : Рута. С. $92-101$.

3. Карабан В.І. Посібник-довідник з перекладу англійської наукової і технічної літератури на українську мову. Частина І. Київ : TEMPUS. $317 \mathrm{c}$.

4. Синдега Р.Є. Структурні особливості функціонування термінів в англомовних текстах 3 проблем комп'ютерних наук та інформаційних технологій. Наукові записки Національного університету «Острозька академія». 2009. Сер.: Філологічна. Вип. 11. С. 351-358.

5. Беценко Т. Історія становлення та формування офіційно-ділового стилю української мови. Наук, вісник ЧНУ: 36. наук, праџь. Слов. філологія. 2001. Вип. 117-118. Чернівці: Рута. С. 45-52.

6. Наконечний Я.В. Лексико-семантична характеристика термінології: [стаття]. Вінницький наиіональний технічний університет. 2016

Мойсеєнко С., Лісецький К., Кондрашова А. Лексико-семантичні особливості термінів сучасного англомовного науково-технічного дискурсу

Анотація. Специфічний характер, прийоми і засоби матеріалізації науково-технічної інформації трансформують і організовують матеріал деяким спеціальним чином. Найважливішу роль при цьому відіграють лінгвістичні фактори, без аналізу яких розуміння науково-технічного тексту навряд чи можливе. Сучасна мова має систему кодів, достатню для передавання будь-якої інформації. У науково-технічній мові основною одиницею системи кодів є термін, тобто слово або словосполучення, що називає наукове і технічне поняття. Організація будь-якої терміносистеми це завжди результат складного і тривалого процесу, оскільки залежить не тільки від ряду факторів та умов, але й від їхньої взаємодії. Терміносистеми в англійській мові безперервно розвиваються та змінюються, відповідаючи викликам сьогодення. Вивчення шаблонів формування словника англійської термінології є надзвичайно важливою складовою частиною для структуризації сучасної науки термінології та лінгвістики. Англійська термінологія є надзвичайно складною та двозначною і постійно абсорбує зміни, тому стає все більш суттєвим процес визначення термінів сучасного наукового та технічного дискурсу в англійській мові. Розширення професійного словника цілком базується на систематизації та класифікації терміносистеми. У статті подано інформацію про лексичні та семантичні особливості термінологічної системи сучасного англомовного науково-технічного дискурсу; з'ясовано специфіку функціонування термінологічної системи шляхом виявлення іiі лексичних, семантичних та структурних особливостей, що також є метою даної роботи. Підкреслюється, що детальне вивчення закономірностей формування термінологічної лексики, iї структури та семантики, з акцентом на англомовній термінологічній системі, $\epsilon$ важливим та необхідним, і це в подальшому дозволить збагатити науково-технічний дискурс. У роботі визначено структурні, лексичні та семантичні особливості термінів. Вказано їхні класифікації та проаналізовано характеристики, за якими вони класифікуються. Вводиться глибоке визначення поняття терміна, його основні характеристики та особливості.

Ключові слова: термін, термінологічна система, мовний знак, лексичні, семантичні та структурні особливості, науково-технічний дискурс, фахова лексика. 